\title{
Who participates in internet-based worksite weight loss programs?
}

\author{
Wen You ${ }^{1 *}$, Fabio A Almeida ${ }^{2}$, Jamie M Zoellner², Jennie L Hill², Courtney A Pinard ${ }^{3}$, Kacie C Allen², \\ Russell E Glasgow ${ }^{4}$, Laura A Linnan ${ }^{5}$ and Paul A Estabrooks ${ }^{2}$
}

\begin{abstract}
Background: The reach and representativeness are seldom examined in worksite weight loss studies. This paper describes and illustrates a method for directly assessing the reach and representativeness of a internet-based worksite weight loss program.
\end{abstract}

Methods: A brief health survey (BHS) was administered, between January 2008 and November 2009, to employees at 19 worksites in Southwest Virginia. The BHS included demographic, behavioral, and health questions. All employees were blinded to the existence of a future weight loss program until the completion of the BHS.

Results: The BHS has a participation rate of 66 percent and the subsequent weight loss program has a participation rate of 30 percent. Employees from higher income households, with higher education levels and health literacy proficiency were significantly more likely to participate in the program ( $p$ 's $<.01$ ).

Conclusions: Worksite weight loss programs should include targeted marketing strategies to engage employees with lower income, education, and health literacy.

\section{Background}

A recent systematic review on the effectiveness of worksite nutrition and physical activity programs for reducing weight in overweight and obese employees found a consistent, but modest, effect of interventions on reductions in body weight (i.e., -2.8 pounds) and body mass index (BMI; i.e., - $0.5 \mathrm{BMI}$ ) when compared to untreated controls [1]. These modest results could have a large public health impact if the intervention strategies could reach a large and representative or high risk sample of employees since the majority of adults spend a large amount of waking hours at work [2]. Unfortunately, few worksite health promotion studies reported on reach, [3] defined as the proportion of the eligible employee population that participated in a program and the representativeness of program participants compared to the eligible population [4]. Specifically, a review of worksite health prevention and intervention programs documented that only $25 \%$ of studies reported the proportion of

\footnotetext{
* Correspondence: wenyou@vt.edu

'Virginia Polytechnic Institute and State University, Dept of Agricultural and Applied Economics, Blacksburg, Virginia, USA

Full list of author information is available at the end of the article
}

eligible employees that agreed to participate in the study and only $9 \%$ reported on representativeness [3].

The current state of worksite intervention studies led the U.S. Preventive Services Task Force to conclude that there is a significant gap related to understanding the characteristics of the employee population that participates [1]. Because of this gap, it is unclear if those who could benefit most from a worksite intervention are as likely to participate as those who may already be making more healthful lifestyle choices [3,5]. This gap is also recognized in the general preventive care intervention research and several calls for better methods for reporting on external validity issues have been made [6-9] Understanding program reach not only would aid in filling the need of examining external validity of the program, but also would provide much needed information for determining whether or not the critical subgroups of employees are actually participating in the program. The results will also inform targeted marketing and recruitment efforts.

However, the documentation of reach and representativeness is predicated on knowing the proportion of eligible employees and having a clear picture of the demographic and behavioral characteristics of the total
C Biomed Central

(c) 2011 You et al; licensee BioMed Central Ltd. This is an Open Access article distributed under the terms of the Creative Commons Attribution License (http://creativecommons.org/licenses/by/2.0), which permits unrestricted use, distribution, and reproduction in any medium, provided the original work is properly cited. 
employee population, and this information has proven difficult to obtain. [e.g., [3,10-12]] Therefore the purpose of this paper is to describe and illustrate a method for directly assessing the reach and representativeness of participants in a worksite weight loss study that focused on changes in physical activity and nutrition.

\section{Methods}

The data presented in this paper were collected as part of a two-group, cluster randomized controlled trial to investigate the reach and effectiveness of individually targeted, computer mediated worksite weight loss programs. The program comprises of emails with physical activity and diet messages that are tailored to the individual and includes small monetary incentives for weightloss. Prior to program initiation a brief health survey (BHS) was administered to as many employees as possible at each participating worksite to determine eligibility, and evaluate reach and potential participation predictors. We administered the BHS between January 2008 and November 2009 with a goal to achieve a 70\% completion rate prior to implementing the worksite weight loss intervention study. The analyses were completed in December 2009.

All employees with the exception of organizational decision-makers (i.e. CEOs and Human Resource Directors) were blinded to the existence of a future weight loss program to be delivered at their worksite, and as such employees' responses were unlikely to be biased by that knowledge. The BHS was introduced to the general employee population as a survey study to provide feedback on areas that the workplace health promotion efforts could focus on. The BHS was available in paperand-pencil and web-based formats, and was delivered to all employees four weeks prior to the weight loss program being initiated. Employees had two weeks to complete the survey. All participating worksites allowed employees to complete the BHS during work hours. While it is noted in the literature that to achieve a 50 percent employee response rate to health risk surveys incentives of approximately $\$ 40$ per employee are necessary when tied with strong organizational communication; [13] providing such incentives was beyond the budget of the project. As a result, a lottery system was installed to encourage the survey participation. Any BHS participant could submit his/her name for a $\$ 250$ prize drawing at each worksite. This study was approved by the Virginia Tech Institutional Review Board (protocol \#07-296).

\section{Worksites and Individual Employees Sample}

Worksite eligibility criteria include internet access at the worksite and employing between 100 and 600 workers at that site. A total of 33 worksites were contacted.
Nineteen agreed to participate in the study. Those that declined invitation did not differ from those that agreed on worksite size, location, or industry. Worksites that agreed to participate in the study included 3 governmental agencies, 5 professional groups, 3 medical facilities, 4 manufacturing and distribution centers, and 4 municipalities (Table 1). Worksites were primarily in urban areas $(\mathrm{n}=16)$ with a small number from rural settings $(\mathrm{n}=3)$.

All employees were eligible to participate in the BHS. Employee eligibility criteria for the subsequent weight loss program include a $\mathrm{BMI}>=25$, regular employment status (e.g., temporary employees were excluded), and access to the internet. Therefore only those employees who were eligible to participate in the weight loss program are included in the analysis of this paper to determine weight loss program participant representativeness to the eligible population. The final analysis included 2,055 participants across 19 worksites ranging in size from 33-95 program participants and 100-589 total employees.

\section{Brief Health Survey Data}

As the primary outcome measure, we created a dummy variable indicating whether an employee enrolled in the subsequent weight loss program or not. Key information collected through the BHS includes: healthy eating,[14] physical activity,[15] health status,[16] health literacy, [17] internet and e-mail use proficiency, self-efficacy,[18] response-efficacy,[19] and demographic variables (i.e., age, gender, race/ethnicity, number of children in the household, household income, and education). We also controlled in our model other factors such as selfreported height and weight, smoking status, and existence of comorbid conditions. Height and weight were used to compute BMI. Smoking status was assessed using a single-item question: "Do you currently smoke?" Comorbid health conditions (arthritis, asthma, depression, diabetes, heart disease, high blood pressure, high cholesterol, obesity, and none of the above) were assessed using a single-item question which respondents checked all conditions that have been diagnosed by a doctor.

\section{Reach and Representativeness Assessment}

The initial reach metric calculated was the proportion of eligible employees (i.e., BMI $>=25$ ) who enrolled in the weight loss program. The numerator for this analysis included all employees who enrolled in the study. The denominator used in this calculation was computed by multiplying the proportion of employees that responded to the BHS with a BMI greater than or equal to 25 by the total number of employees at the worksite to extrapolate to all eligible employees rather than just those 
Table 1 Participation Rates By Worksite

\begin{tabular}{|c|c|c|c|c|}
\hline \multirow[b]{2}{*}{ Worksite } & \multicolumn{3}{|c|}{ BHS } & \multirow[b]{2}{*}{$\begin{array}{c}\text { Program Participation } \\
\text { Rate among Eligible } \\
\text { Employees }\end{array}$} \\
\hline & $\begin{array}{l}\text { Number of } \\
\text { Employees }\end{array}$ & $\begin{array}{c}\text { Completion } \\
\text { Rate }\end{array}$ & $\begin{array}{l}\text { \% Eligible among those } \\
\text { completed the BHS } \\
(\mathrm{BMI}>=25)\end{array}$ & \\
\hline \multicolumn{5}{|c|}{ Governmental Agencies } \\
\hline Worksite 1 & 100 & $95 \%$ & $79 \%$ & $49 \%$ \\
\hline Worksite 2 & 315 & $63 \%$ & $71 \%$ & $33 \%$ \\
\hline Worksite 3 & 276 & $63 \%$ & $83 \%$ & $17 \%$ \\
\hline \multicolumn{5}{|c|}{ Professional Groups } \\
\hline Worksite 4 & 589 & $49 \%$ & $73 \%$ & $22 \%$ \\
\hline Worksite 5 & 435 & $61 \%$ & $50 \%$ & $23 \%$ \\
\hline Worksite 6 & 305 & $30 \%$ & $69 \%$ & $19 \%$ \\
\hline Worksite 7 & 238 & $67 \%$ & $81 \%$ & $17 \%$ \\
\hline Worksite 8 & 253 & $77 \%$ & $75 \%$ & $23 \%$ \\
\hline \multicolumn{5}{|c|}{ Medical Facilities } \\
\hline Worksite 9 & 246 & $83 \%$ & $72 \%$ & $47 \%$ \\
\hline Worksite 10 & 291 & $79 \%$ & $80 \%$ & $28 \%$ \\
\hline Worksite 11 & 477 & $70 \%$ & $70 \%$ & $19 \%$ \\
\hline \multicolumn{5}{|c|}{ Manufacturing and Distribution Centers } \\
\hline Worksite 12 & 197 & $72 \%$ & $77 \%$ & $23 \%$ \\
\hline Worksite 13 & 243 & $58 \%$ & $67 \%$ & $21 \%$ \\
\hline Worksite 14 & 353 & $61 \%$ & $72 \%$ & $18 \%$ \\
\hline Worksite 15 & 297 & $71 \%$ & $73 \%$ & $27 \%$ \\
\hline \multicolumn{5}{|c|}{ Municipalities } \\
\hline Worksite 16 & 350 & $58 \%$ & $72 \%$ & $30 \%$ \\
\hline Worksite 17 & 219 & $80 \%$ & $74 \%$ & $38 \%$ \\
\hline Worksite 18 & 185 & $58 \%$ & $92 \%$ & $20 \%$ \\
\hline Worksite 19 & 206 & $54 \%$ & $86 \%$ & $20 \%$ \\
\hline Average & 293 & $66 \%$ & $75 \%$ & $26 \%$ \\
\hline Median & 276 & $63 \%$ & $73 \%$ & $23 \%$ \\
\hline Minimum & 100 & $30 \%$ & $50 \%$ & $17 \%$ \\
\hline Maximum & 589 & $95 \%$ & $92 \%$ & $49 \%$ \\
\hline
\end{tabular}

Note: BHS - Brief Health Survey; BMI - Body Mass Index.

who completed the BHS. Representativeness was calculated by comparing those eligible employees that participated in the program to eligible employees that did not participate in the program, but completed the BHS. In addition, there were a significant number of employees across worksites $(n=398)$ that participated in the program but did not complete the BHS. Thus we also compared these participants to those that completed the survey. This comparison allowed us to determine if those employees with a $\mathrm{BMI} \geq 25$ who responded to the BHS were representative of those who did not.

\section{Weight Loss Program Reach Prediction}

We used a multi-level mixed effect logit model treating the employees as nested within worksite, which is equivalent to estimating random intercept models assuming the unobserved worksite-specific effects are not correlated with predictors in the model. The model allows us to apply the study results to general worksite populations. The variety of worksites in the program, shown in Table 1, supports the population inference as well.

\section{Results}

\section{Reach and Representativeness Assessment}

The BHS and the weight loss program reach rates are presented in Table 1. Across the 19 worksites enrolled in the study, the BHS participation rate on average is $66 \%$ with a median of $63 \%$ and ranged from $30 \%$ to $95 \%$. For the weight loss program, the participation rate among the entire potentially eligible population ranged from $17 \%$ to $49 \%$ with a mean of $26 \%$ and a median of $23 \%$.

Table 2 presents the representativeness assessment results. We used the BHS data to estimate reach therefore our sample is limited to the 2,055 individuals who 
Table 2 Representativeness of Brief Health Survey (BHS) and the Weight Loss Program

\begin{tabular}{|c|c|c|c|c|c|c|c|}
\hline & $\begin{array}{c}\text { Reach } \\
\text { Study } \\
\text { Sample } \\
(\mathrm{n}=2,055)\end{array}$ & $\begin{array}{c}\text { BHS \& } \\
\text { Program } \\
\text { Participants } \\
(n=610)\end{array}$ & $\begin{array}{l}\text { BHS Participants } \\
\text { Program } \\
\text { Nonparticipants } \\
(n=1,445)\end{array}$ & $\begin{array}{l}\text { BHS Nonparticipants } \\
\text { Program Participants } \\
\qquad(\mathrm{n}=398)\end{array}$ & $\begin{array}{l}\text { Group } \\
\text { Mean } \\
\text { Test } p- \\
\text { value }\end{array}$ & $\begin{array}{l}\text { Group } \\
\text { Mean } \\
\text { Test } p \text { - } \\
\text { value }\end{array}$ & $\begin{array}{l}\text { Group Mean } \\
\text { Test } p \text {-value }\end{array}$ \\
\hline Variables & Mean (1) & Mean (2) & Mean (3) & Mean (4) & $\begin{array}{c}\operatorname{Mean}(2)= \\
\operatorname{Mean}(3)\end{array}$ & $\begin{array}{c}\text { Mean(2) = } \\
\text { Mean(4) }\end{array}$ & $\begin{array}{c}\text { Mean }(1)= \\
\operatorname{Mean}(4)\end{array}$ \\
\hline Age & 45.4 & 46.6 & 44.8 & 45.1 & $0.001^{* * *}$ & 0.034 & 0.706 \\
\hline Female, \% & 59.1 & 74.9 & 52.5 & 74.6 & $0.000^{* * *}$ & 0.916 & $0.000^{* * *}$ \\
\hline Hispanic origin, \% & 2.2 & 1.5 & 2.5 & 4.5 & 0.112 & $0.008^{* * *}$ & $0.007^{* * *}$ \\
\hline \multicolumn{8}{|l|}{ Race, \% } \\
\hline Caucasian & 71.7 & 79.7 & 68.3 & 69.3 & $0.000^{* * *}$ & $0.000^{* * *}$ & 0.347 \\
\hline $\begin{array}{l}\text { African } \\
\text { American }\end{array}$ & 24.6 & 18.0 & 27.3 & 25.1 & $0.000^{* * *}$ & $0.008^{* * *}$ & 0.815 \\
\hline Asian & 1.2 & 0.3 & 1.5 & 1.3 & $0.003^{* * *}$ & 0.126 & 0.881 \\
\hline Other & 2.6 & 2.0 & 2.8 & 4.3 & 0.222 & 0.048 & 0.064 \\
\hline \multicolumn{8}{|l|}{ Education, \% } \\
\hline $\begin{array}{l}\text { Less than high } \\
\text { school }\end{array}$ & 2.0 & 0.3 & 2.7 & 1.5 & $0.000^{* * *}$ & 0.072 & 0.516 \\
\hline $\begin{array}{l}\text { High school } \\
\text { graduate }\end{array}$ & 17.2 & 13.1 & 19.9 & 12.8 & $0.008^{* * *}$ & 0.890 & 0.032 \\
\hline Some college & 30.3 & 33.9 & 28.7 & 29.9 & 0.021 & 0.178 & 0.884 \\
\hline $\begin{array}{l}\text { College } \\
\text { graduate }\end{array}$ & 34.1 & 36.4 & 33.1 & 37.2 & 0.160 & 0.799 & 0.238 \\
\hline $\begin{array}{l}\text { Post graduate/ } \\
\text { professional }\end{array}$ & 16.4 & 16.2 & 16.5 & 18.6 & 0.862 & 0.337 & 0.295 \\
\hline \multicolumn{8}{|l|}{$\begin{array}{l}\text { Annual household } \\
\text { Income, \% }\end{array}$} \\
\hline $\begin{array}{l}\text { Less than } \\
\$ 15,000\end{array}$ & 2.0 & 0.3 & 2.7 & 2.3 & $0.000^{* * *}$ & 0.014 & 0.731 \\
\hline $\begin{array}{l}\$ 15,000- \\
\$ 29,999\end{array}$ & 12.5 & 8.2 & 14.3 & 11.8 & $0.000^{* * *}$ & 0.066 & 0.719 \\
\hline $\begin{array}{l}\$ 30,000- \\
\$ 49,999\end{array}$ & 24.1 & 25.9 & 23.4 & 22.6 & 0.231 & 0.232 & 0.514 \\
\hline $\begin{array}{l}\$ 50,000- \\
\$ 99,999\end{array}$ & 41.7 & 43.9 & 40.8 & 38.9 & 0.185 & 0.116 & 0.306 \\
\hline $\begin{array}{l}\text { More than } \\
\$ 100,000\end{array}$ & 19.7 & 21.6 & 18.9 & 24.4 & 0.162 & 0.316 & 0.035 \\
\hline $\begin{array}{l}\text { Have at least one } \\
\text { child, \% }\end{array}$ & 50.8 & 49.7 & 51.3 & 56.3 & 0.506 & 0.040 & 0.045 \\
\hline
\end{tabular}

completed the BHS. Among this sample, 610 employees enrolled in the weight loss program. The average participant was about 45 years old, with $59 \%$ being female and $72 \%$ being Caucasian, 25\% African American, and $2.2 \%$ Hispanic. In general, participants were educated with $50 \%$ having college or professional/graduate degrees and $61 \%$ reported annual household earnings of $\$ 50,000$ or more (Table 2).

There were a total of 398 employees who did not complete the BHS but enrolled in the program. Those individuals were not in the program reach predication model analysis since their BHS data was missing. We compared their characteristics with the 610 program participants who completed BHS to assess the representativeness of our BHS sample. The seventh column of
Table 2 presents the test results (i.e., comparing Mean (2) and Mean(4)). Majority of comparisons did not show statistically significant differences except for race/ethnicity which shows a relatively good representability of our BHS sample. However, those program participants who did not participate in the BHS on average were more likely to be Hispanic, or African American, and less likely to be Caucasian (p's < .01). To further assess the BHS representativeness, we compare those BHS participants with those 398 BHS nonparticipants. Results are shown in the last column of Table 2 (i.e., comparing Mean(1) and Mean(4)). It further confirms that our BHS sample is mostly representative except that female employees and those of Hispanic origin are less likely to fill out the BHS survey. 
The results of the comparison test to assess the program participant representativeness are shown in the sixth column of Table 2 (i.e., comparing Mean(2) and Mean(3)). Statistically significant differences were detected comparing age, gender, proportion of Caucasian, African American, Asian, education level lower than some college, and income level lower than $\$ 30,000 / \mathrm{yr}$.

\section{Reach Prediction Model}

Table 3 provides the variable descriptions and summary statistics for variables of interest. Across worksites, weight loss program participation rate was 30\% among those eligible employees who completed the BHS. The participation rate ranges across worksites between 20$50 \%$. The participants reported relatively healthy eating habits, 5.93 (on a 14-pt scale with lower scores reflect more healthful eating patterns), but were generally inactive (1.66 on the 3 -pt scale where 3 equals meeting recommended guidelines). There is wider variability in healthy eating habits than physical activity. Eighteen percent were current smokers and 56\% reported at least one chronic health condition. The average BMI was 32, with a range of 25-64. The average health literacy score was also high (13 on the 15-pt scale). The 19 worksites in this study exhibit similar patterns overall but have sizable variations in terms of BMI and healthy eating behavior (with $S D>0.5$ ).

The multi-level mixed effect logit model was significant (Wald Test, $\chi^{2}=172.35, p<.000$ ) and the Likelihood Ratio test was significant $(5.81, \mathrm{p}<.01)$ indicating that the model was more appropriate than the standard logit model (Table 4). The odds of a female employee participating in the program are 3.3 times higher than their male counterparts while those African American and Asian employees are less likely to participate in the program compared to Caucasian employees. For a one category increase in household income and education level, odds of participation increased by $16 \%$ and $12 \%$ respectively. One unit score increase of BMI will increase the odds of participation by about $3 \%$. The odds of participation are 1.56 times higher for non-smokers and 1.23 times higher for employees reporting existing health conditions. An increase in health literacy score by one unit resulted in an $8 \%$ increase in the odds of program participation. Physical activity level, healthy

Table 3 Variable Descriptions and Summary Statistics across Sample and Worksites

\begin{tabular}{|c|c|c|c|c|c|}
\hline \multirow[b]{2}{*}{$\mathrm{N}=2,055$} & \multirow[b]{2}{*}{ Description } & \multicolumn{2}{|c|}{$\begin{array}{c}\text { Individual } \\
\text { Level }\end{array}$} & \multicolumn{2}{|c|}{$\begin{array}{l}\text { Worksite } \\
\text { Level }\end{array}$} \\
\hline & & $\begin{array}{l}\text { Mean } \\
\text { (SD) }\end{array}$ & Range & $\begin{array}{l}\text { Mean } \\
\text { (SD) }\end{array}$ & Range \\
\hline \multicolumn{6}{|l|}{$\begin{array}{l}\text { Outcome } \\
\text { Variable }\end{array}$} \\
\hline Participation & Dummy (= 1 if participate in the program; = 0 if not) & $\begin{array}{c}0.30 \\
(0.46)\end{array}$ & $0-1$ & $\begin{array}{c}0.30 \\
(0.08)\end{array}$ & $\begin{array}{l}0.2- \\
0.5\end{array}$ \\
\hline \multicolumn{6}{|l|}{$\begin{array}{l}\text { Independent } \\
\text { Variables }\end{array}$} \\
\hline BMI & Body mass index score $\left(\mathrm{kg} / \mathrm{m}^{2}\right)$ & $\begin{array}{c}31.7 \\
(5.75)\end{array}$ & $\begin{array}{l}25.0- \\
63.7\end{array}$ & $\begin{array}{c}31.7 \\
(1.27)\end{array}$ & $\begin{array}{l}29.1- \\
33.9\end{array}$ \\
\hline Physical Activity & Rank (= 1 inactive; $=2$ MSR or $M C V_{i}=3$ Meeting recommendations) & $\begin{array}{c}1.66 \\
(0.78)\end{array}$ & $1-3$ & $\begin{array}{c}1.66 \\
(0.14)\end{array}$ & $\begin{array}{l}1.5- \\
2.0\end{array}$ \\
\hline Healthy Eating & Healthy eating scores. Lower scores means healthier eating habits & $\begin{array}{c}5.93 \\
(2.52)\end{array}$ & $0-14$ & $\begin{array}{c}5.93 \\
(0.58)\end{array}$ & $\begin{array}{l}4.9- \\
7.0\end{array}$ \\
\hline $\begin{array}{l}\text { Overall Health } \\
\text { Status }\end{array}$ & Ranked self-reported health status (1 excellent to 5 poor) & $\begin{array}{c}2.87 \\
(0.83)\end{array}$ & $1-5$ & $\begin{array}{c}2.87 \\
(0.16)\end{array}$ & $\begin{array}{c}2.6- \\
3.1\end{array}$ \\
\hline $\begin{array}{l}\text { Comorbid } \\
\text { Conditions }\end{array}$ & $\begin{array}{l}\text { Dummy ( } 1 \text { if has at least one comorbidity; }=0 \text { if has no other health } \\
\text { conditions other than obesity) }\end{array}$ & $\begin{array}{c}0.56 \\
(0.50)\end{array}$ & $0-1$ & $\begin{array}{l}0.56 \\
(0.07)\end{array}$ & $\begin{array}{l}0.4- \\
0.7\end{array}$ \\
\hline Smoking & Dummy (= 1 if current smoker; = 0 otherwise) & $\begin{array}{l}0.18 \\
(0.39)\end{array}$ & $0-1$ & $\begin{array}{l}0.18 \\
(0.08)\end{array}$ & $\begin{array}{l}0.1- \\
0.3\end{array}$ \\
\hline Health Literacy & Health literacy scores. Higher scores means better health literacy. & $\begin{array}{l}13.25 \\
(1.91)\end{array}$ & $3-15$ & $\begin{array}{l}13.25 \\
(0.44)\end{array}$ & $\begin{array}{l}12.0- \\
14.0\end{array}$ \\
\hline Internet Use & Self efficacy in internet use. Higher scores means higher efficacy. & $\begin{array}{c}3.59 \\
(1.61)\end{array}$ & $1-5$ & $\begin{array}{c}3.59 \\
(0.22)\end{array}$ & $\begin{array}{l}3.2- \\
4.2\end{array}$ \\
\hline Email Use & Self efficacy in email use. Higher scores means higher efficacy. & $\begin{array}{c}3.60 \\
(1.64)\end{array}$ & $1-5$ & $\begin{array}{c}3.6 \\
(0.25)\end{array}$ & $\begin{array}{c}3.1- \\
4.2\end{array}$ \\
\hline
\end{tabular}


Table 4 Program Participation Multi-level Mixed Effect Logit Model Results

\begin{tabular}{|c|c|c|c|c|}
\hline & OR & SE & $\mathrm{p}$-value & $\mathrm{Cl}(95 \%)$ \\
\hline BMl & $1.03^{* * *}$ & 0.01 & 0.002 & $1.01-1.05$ \\
\hline Physical Activity & 0.89 & 0.07 & 0.130 & $0.77-1.03$ \\
\hline Healthy Eating & 1.01 & 0.02 & 0.693 & $0.97-1.05$ \\
\hline Overall Health Status & 1.01 & 0.07 & 0.848 & $0.88-1.17$ \\
\hline Comorbid Health Conditions & $1.23^{*}$ & 0.14 & 0.075 & $0.98-1.53$ \\
\hline Smoking & $0.64^{* * *}$ & 0.09 & 0.002 & $0.48-0.85$ \\
\hline Health Literacy & $1.08^{* *}$ & 0.03 & 0.013 & $1.02-1.15$ \\
\hline Female & $3.26^{* * *}$ & 0.40 & 0.000 & $2.56-4.13$ \\
\hline Age & $1.01^{* *}$ & 0.005 & 0.031 & $1.00-1.02$ \\
\hline \multicolumn{5}{|l|}{ Race (Caucasian is the base) } \\
\hline African American & $0.51^{* * *}$ & 0.07 & 0.000 & $0.38-0.67$ \\
\hline Asian & $0.25^{*}$ & 0.19 & 0.067 & $0.06-1.10$ \\
\hline Other & 0.79 & 0.28 & 0.505 & $0.39-1.60$ \\
\hline Hispanic & 0.61 & 0.25 & 0.225 & $0.27-1.36$ \\
\hline Education & $1.12^{* *}$ & 0.07 & 0.069 & $0.99-1.26$ \\
\hline Income & $1.16^{* *}$ & 0.07 & 0.015 & $1.03-1.31$ \\
\hline Have at least one child & 1.08 & 0.12 & 0.452 & $0.88-1.34$ \\
\hline Wald chi2 & 172.35 & & 0.000 & \\
\hline LR (mixed effect logit vs. normal logit) & 5.81 & & 0.008 & \\
\hline
\end{tabular}

Note: OR - odds ratio; SE - standard errors; $\mathrm{Cl}$ - confidence intervals;

${ }^{*} \mathrm{p}<0.1,{ }^{* *} \mathrm{p}<0.05$, ${ }^{* * *} \mathrm{p}<0.01$.

eating behaviors, self-reported overall health status, other race compared to Caucasian, and Hispanic origin are not significant predictors.

\section{Discussion and Conclusion}

This paper describes an initial attempt at addressing the paucity in the research literature on the reach of worksite-based weight loss programs. Consistent with the literature, we found that older Caucasian women were more likely to participate in worksite weight loss programs $[5,12]$. Of note, even though the weight loss programs were internet-based more women than men as well as older people were willing to participate suggesting that digital divide stereotypes may not apply in this context [20]. Our study also adds to the literature and suggests that participants are more likely to have a chronic condition, higher BMI, and higher health literacy than the overweight and obese employees that choose not to participate.

A primary goal of this paper was to present a method to assess reach and representativeness in the context of worksite weight loss programs. While it would have been ideal to achieve a $100 \%$ completion rate of the BHS, the average completion rate of approximately two thirds of the employee population reflects a strong response rate relative to other worksite health risk appraisal completion data [13]. This suggests that a lottery incentive system, when coupled with strong organizational communication strategies, could be as effective as individual level incentives. Further, our study also provides researchers a more cost effective method of achieving a greater than 50 percent BHS response rate.

We also found that African American and Asian employees were about one-half and one-quarter less likely than Caucasians to participate, respectively. Similar to the need to use culturally sensitive strategies within weight loss programs for diverse employee populations, [21,22] our findings suggest the need to also develop culturally-tailored recruitment tactics and materials. For example, African Americans may be less likely to perceive themselves as overweight and more likely to associate attractiveness and health status with heavier body size when contrasted with Caucasians [23,24]. For these reasons, programs that focus on outcomes aside from weight loss such as obesity-related co-morbid conditions or improved job performance and satisfaction may promote higher participation among African Americans. Similarly, employees with lower health literacy were found to be less likely to participate in the program which confirms the important implications of health literacy status in the context of recruiting and retaining participants $[25,26]$. Our study directly assessed health literacy as a characteristic impacting enrollment which no known study has done before.

Limitations of this study include varying participation rates in surveys and an average BHS completion rate of approximately $66 \%$. Although conducting a thorough examination of potential non-response bias was beyond 
the scope of this study,[27] we did calculate adjusted reach estimates to account for these differences and provide comparison tests to assess BHS representativeness (Table 2). In contrast study strengths include a diverse set of worksites, a range of demographic, behavioral, and health literacy indicators; the study of both survey and program participation; and adjustments for clustering of employees within worksites.

The use of a BHS to provide information on employee characteristics and eligibility provides an opportunity to determine more accurate indicators of reach and representativeness. As reach and representativeness have received limited attention in worksite health promotion research, [3] it is necessary to persist in collection and reporting of these types of data. The approach utilized in our study appears to be feasible and appropriate for use in future research.

\begin{abstract}
Acknowledgements
We would like to thank all partners at each of the worksites that agreed to participate in the study. We would also like to acknowledge the work of Sarah Wall and Jennifer Parrish for coordinating and implementing the recruitment protocol necessary for this study. This study is supported by a grant from the National Institute for Diabetes and Digestive and Kidney Diseases: 5R01DK071664-04 (Estabrooks, PI).
\end{abstract}

\section{Author details}

${ }^{1}$ Virginia Polytechnic Institute and State University, Dept of Agricultural and Applied Economics, Blacksburg, Virginia, USA. Virginia Polytechnic Institute and State University, Dept of Human Nutrition Foods, \& Exercise, Blacksburg, Virginia, USA. ${ }^{3}$ Gretchen Swanson Center for Human Nutrition, Omaha Nebraska, USA. ${ }^{4}$ Dissemination and Implementation Science Division of Cancer Control and Population Sciences, NCl, Rockville, Maryland, USA. ${ }^{5}$ University of North Carolina, Dept of Health Behavior and Health Education, Chapel Hill, North Carolina, USA.

\section{Authors' contributions}

WY participated in the design of the study, performed the statistical analysis and drafted the manuscript. FA participated in the study design, lead and manage the acquisition of data, and was involved in drafting the manuscript. $J Z, J H, C P$, and KA participated in interpretation of results and were involved in drafting of the manuscript. RG and $L L$ contributed in drafting the manuscript and the design of the study. PE conceived of the study, lead the study design, contributed in statistical analysis and results interpretation, coordinated and participated in the drafting of the manuscript. All authors read and approved the final manuscript.

\section{Competing interests}

The authors declare that they have no competing interests.

Received: 26 May 2011 Accepted: 20 September 2011

Published: 20 September 2011

\section{References}

1. Anderson LM, Quinn TA, Glanz K, et al: The effectiveness of worksite nutrition and physical activity interventions for controlling employee overweight and obesity: a systematic review. Am J Prev Med 2009, 37:340-357.

2. Estabrooks PA, Glasgow RE: Worksite interventions. In Cambridge Handbook of Psychology, Health and Medicine. Edited by: Ayers S, Baum A, McManus C, Newman S, Wallston K, Weinman J, West R. New York: Cambridge University press; 2007:

3. Bull SS, Gillette C, Glasgow RE, Estabrooks P: Work site health promotion research: To what extent can we generalize the results and what is needed to translate research to practice? Health Educ Behav 2003, 30:537-549.

4. Glasgow RE, Vogt TM, Boles SM: Evaluating the public health impact of health promotion interventions: the RE-AIM framework. Am J Public Health 1999, 99:1322-1327.

5. Linnan LA, Emmons KM, Klar N, Fava JL, LaForge RG, Abrams DB: Challenges to improving the impact of worksite cancer prevention programs: comparing reach, enrollment, and attrition using active versus passive recruitment strategies. Ann Behav Med 2002, 24:157-166

6. Glasgow RE, Bull SS, Gillette C, Klesges LM, Dzewaltowski DA: Behavior change intervention research in healthcare settings: a review of recent reports with emphasis on external validity. Am J Prev Med 2002, 23:62-69.

7. Glasgow RE, Nelson CC, Strycker LA, King DK: Using RE-AIM metrics to evaluate diabetes self-management support interventions. Am J Prev Med 2006, 30:67-73.

8. Glasgow RE, Emmons KM: How can we increase translation of research into practice? Types of evidence needed. Annu Rev Publ Health 2007, 28:413-433.

9. Glasgow RE, Linnan L: Evaluation of theory-based interventions. In Health Behavior and Health Education: Theory, Practice and Research.. 4 edition. Edited by: Glanz K, Rimer B, Vishwanath V. San Francisco: Jossey-Bass Publishers; 2008:

10. Franklin PD, Rosenbaum PF, Carey MP, Roizen MF: Using sequential email messages to promote health behaviors: evidence of feasibility and reach in a worksite sample. J Med Internet 2006, Re. 8, e3.

11. Glasgow RE, Mccaul KD, Fisher KJ: Participation in worksite health promotion - a critique of the literature and recommendations for future practice. Health Edu Quar 1993, 20:391-408.

12. Robroek SJW, Lenthe FJV, Empelen PV, Burdorf A: Determinants of participation in worksite health promotion programmes: a systematic review. Int J Behav Nutr Phy 2009, 6:26.

13. Taitel MS, Haufle V, Heck D, Loeppke R, Fetterolf D: Incentives and other factors associated with employee participation in health risk assessments. J Occup Environ Med 2008, 50:863-72.

14. Ammerman $A$, Haines $P$, DeVellis $R$, et al: $A$ brief dietary assessment to guide cholesterol reduction in low income individuals: design and validation. JADA 1991, 91:1385-1390.

15. Macera CA, Pratt C: Public health surveillance of physical activity. Res $Q$ Exercise and Sport 2000, 71:97-103.

16. Scientific Advisory Committee of the Medical Outcomes Trust: Assessing health status and quality-of-life instruments: attributes and review criteria. Quality of Life Research 2002, 11:193-205.

17. Chew LD, Bradley KA, Boyko EJ: Brief questions to identify patients with inadequate health literacy. Fam Med 2004, 36:588-594.

18. Schwarzer R, Renner B: Social-cognitive predictors of health behavior: action self-efficacy and coping self-efficacy. Health Psychology 2000, 19:487-495.

19. Plotnikoff RC, Higginbotham N: Protection motivation theory and exercise behaviour change for the prevention of coronary heart disease in a high risk, Australian representative community sample of adults. Psychology, Health and Medicine 2002, 7:87-98.

20. Wilson JJ, Mick R, Wei SJ, et al: Clinical trial resources on the Internet must be designed to reach underrepresented minorities. Cancer J 2006, 12:475-481.

21. Kumanyika S, Whitt-Glover M, Gary TL, et al: Expanding the obesity research paradigm to reach African American communities. Prev Chronic Dis 2007, 4:A112

22. Zapka J, Lemon SC, Estabrook B, Rosal MC: Factors related to weight loss behavior in a multiracial/ethnic workforce. Ethn Dis 2009, 19:154-160.

23. Johnson-Taylor WL, Fisher RA, Hubbard VS, Starke-Reed P, Eggers PS: The change in weight perception of weight status among the overweight: comparison of NHANES III (1988-1994) and 1999-2004 NHANES. Int J Behav Nutr Phys Act 2008, 5:9.

24. Thomas A, Moseley G, Stallings R, Nichols-English G, Wagner PJ: Perceptions of obesity: black and white differences. J Cult Divers 2008 15:174-180.

25. Frew PM, Rio C, Lu L, Clifton S, Mulligan MJ: Understanding differences in enrollment outcomes among high-risk populations recruited to a phase Ilb HIV vaccine trial. J Acquired Immune Deficiency Syndromes 2009, 50:314-319. 
26. Mancuso CA, Rincon M: Impact of health literacy on longitudinal asthma outcomes. J General Internal Med 2006, 21:813-817.

27. Lee $\mathrm{S}$, Brown ER, Grant D, Belin TR, Brick JM: Exploring nonresponse bias in a health survey using neighborhood characteristics. Am J Public Health 2009, 99:1811-1817.

Pre-publication history

The pre-publication history for this paper can be accessed here: http://www.biomedcentral.com/1471-2458/11/709/prepub

doi:10.1186/1471-2458-11-709

Cite this article as: You et al.: Who participates in internet-based worksite weight loss programs? BMC Public Health 2011 11:709.

Submit your next manuscript to BioMed Central and take full advantage of:

- Convenient online submission

- Thorough peer review

- No space constraints or color figure charges

- Immediate publication on acceptance

- Inclusion in PubMed, CAS, Scopus and Google Scholar

- Research which is freely available for redistribution

Submit your manuscript at www.biomedcentral.com/submit 